\title{
Research on "Internet Plus" Curriculum Reform for Modern Agricultural Specialty Group in Higher Vocational Education
}

\author{
Cuihua Sun ${ }^{\mathrm{a}}$, Feng Wang ${ }^{\mathrm{b}^{*}}$, Zhaoxiao $\mathrm{Yu}^{\mathrm{c}}$ and Liang Xue ${ }^{\mathrm{d}}$ \\ Smart Agriculture collage, Suzhou Polytechnic Institute of Agriculture, Suzhou 215008, China \\ a sun2182@163.com, bcfwf96@163.com, c106328487@qq.com, d61230375@qq.com \\ * The corresponding author
}

Keywords: Agricultural specialty group; Internet plus; Curriculum reform; Information course

\begin{abstract}
Through the analysis of the present stage of China's Higher Vocational Curriculum System of modern agricultural information problems, changes of modern agricultural talents demand of "Internet plus modern agriculture" under the new situation, the construction of "knowledge structure Internet plus" technology in modern agricultural professional group, puts forward some countermeasures and suggestions of information system integrated curriculum structure optimization, content integration, teaching mode and evaluation mechanism, the formation of information technology and modern agricultural professional integration program, through the "implantation + optimization" mode, adjust teaching content of basic computer courses, into a digital agricultural technology and the application of information technology courses in the curriculum system of modern agriculture, agricultural information technology to reconstruct the modern professional group curriculum system, training to adapt to the "Internet plus modern agriculture" the requirements of the modern agricultural technology talents.
\end{abstract}

\section{Introduction}

In the "Internet plus" under the background of information system courses in agricultural higher vocational education content is too outdated, update speed lags behind the development of education and teaching, although the "Internet plus" era to promote agricultural specialty informatization courses to make some adjustments, but little, "the core thinking Internet plus" not deep into the system of professional in the course of agricultural higher vocational education[1], still retains the traditional teaching mode, course content did not change. As in many higher vocational colleges to carry out public computer course in the teaching process of computer basic curriculum content of different majors are exactly the same, no special outstanding agricultural class, many teachers in the public computer course teaching process, mainly used to explain the traditional computer based teaching course[2], students can learn the basic knowledge of computer operation, but can't be used to enhance the agricultural professional learning and work, in view of the lack of certain.

\section{Present Situation Analysis}

Application of "Internet plus" in Modern Agriculture. In 2017 the government work report, Premier Li Keqiang made an important deployment of the "three rural" work[3], pointed out the need to side structural reform as the main line to promote agricultural supply, promote the adjustment of agricultural structure, strengthen the construction of modern agriculture, deepen rural reform, strengthen rural public Shi Jianshe, accelerate the development of new energy for the development of agriculture and rural areas. "Internet plus" as a new driving force to promote agricultural supply side structural reform, create new formats and new industries, plays an important role in the development of modern agriculture.

The application of Internet technology in modern agriculture[4], "Internet plus production" helped agricultural precision, "Internet plus information", "intelligent decision Internet plus operation" to achieve high standards and high efficiency production in the new marketing mode[4], 
the rural electricity supplier intervention is helpful to improve the agricultural economic benefits, "the Internet and management" to strengthen the agricultural e-government construction, "Internet plus service" to meet the diverse needs of farmers, and the "Internet plus" to promote the whole industry chain of agriculture and rural development of the depth of integration management. The two-dimensional code first appeared as the 2017 report on the work of the government as well as in the Internet era officially opened[5], "Internet plus" has the power to promote the development of modern agriculture in China, the rural electricity supplier progress of agriculture industry chain extension, agricultural supply side structural reform without means "Internet plus" the important position in modern agriculture. Jiangsu Provincial Agriculture Commission Director Peiliang Wu in an interview with reporters, said: "we must insist on innovation driven, through the mobile Internet, big data, cloud computing, networking and other modern information technology and integration of agriculture depth, let 'Internet plus' become an important engine for the construction of modern agriculture, promote agricultural transformation and upgrading, and strive to achieve the 'Internet plus' agriculture 'Jiangsu create'"[6].

Research on the Current Situation of Computer Courses in the Modern Agricultural Specialty Group. Through the investigation of Jiangsu Province three vocational colleges of agriculture, Jiangsu agriculture and animal husbandry science and technology Career Academy (the national model of higher occupation colleges (Jiangsu Polytechnic College of Agriculture and Forestry), national demonstration (backbone) of higher occupation colleges) and the Suzhou Agricultural Vocational College, the professional curriculum system of modern agricultural industry cluster as the research object, through the investigation, found that most of the modern agricultural professional group only open the computer application basic course, opened a few professional technology course of agricultural IOT, has not formed the information-based course system, unable to meet the needs of modern agriculture Internet plus "[7].

The political Culture for Enterprise Cooperation is Committed to "Internet Plus" Modern Agricultural Talents. In November 2016, the national agricultural occupation education teaching guidance committee under the support of "teaching wisdom agriculture Chinese alliance" was founded at Suzhou Agricultural Vocational College, modern agriculture alliance to service for the purpose, in order to improve the teaching quality as the goal, to the sharing of resources and complementary advantages[8], combined with public relations, service teaching focus, dedicated to accelerating the wisdom of agricultural talents cultivation provide personnel support, "Internet plus" modern agricultural operations.

\section{Curriculum Reform}

"set a New Trend of Internet Plus" of Higher Vocational Education under the Modern Agricultural Informationization Curriculum Professional Group. "Internet plus" connected to the production, circulation and service parts of agriculture, promote the integration of the 123 industry, the information technology into the whole industry chain of agricultural technology development, talent is the key, in this context, analysis of modern agriculture "Internet plus" technology is the core of jobs and skills, such as agricultural data processing technology remote sensing (RS), global positioning system (GPS), geographic information system (GIS), expert system and decision support system, agricultural technology, agricultural system simulation and application of machine vision technology, agricultural database and management information system, precision agriculture, intelligent agricultural information service platform, traceability of agricultural products, on the basis of the content of information construction module curriculum, focus on the information needed to adapt to the construction of courses and technical talents in developing modern agriculture in Jiangsu[7].

"Internet Plus" under the Background of Integration of Informatization of Curriculum and Curriculum of Modern Agricultural System. According to the different needs of Different Agricultural Majors in information technology, we build "basic + compulsory + selective" agricultural information curriculum system [8], that is, computer application foundation course $+\mathrm{a}$ 
number of compulsory courses of agricultural information + some agricultural information elective courses.

Using the "1 $+\mathrm{X}+\mathrm{Y}$ " scheme, we focus on how to put the agricultural information curriculum into the agricultural curriculum system in different levels, categories and stages.

"Internet Plus" Teaching Model and Evaluation Model. To study the "Internet plus" era teaching mode, "imagine Internet plus education into higher vocational curriculum reform of modern agriculture, mainly from two aspects: (1) the creation of" breakthrough mobile Internet plus education "new" Internet plus "teaching model and evaluation model; (2)" teaching mode and evaluation mode cloud + client + education ", the use of cloud computing technology, cloud to create virtual teaching platform, and gradually realize the" online teaching, online operation, cloud storage, cloud terminal sharing "and" teaching mode".

\section{Practical Significance}

As an important part of higher vocational education, the goal of agricultural higher vocational education is to train high-quality skilled talents to meet the needs of modern agricultural production, construction, management and service, and to meet the needs of individual development of students. Therefore, the modern agriculture vocational professional group "Internet plus" curriculum reform research has important theoretical and practical significance.

In higher vocational professional group "modern agricultural research Internet plus" curriculum reform, is the theory construction of higher occupation education in agriculture.

The conclusion of this study will become part of the system construction of agricultural talents training in agricultural vocational colleges, higher vocational education of modern agricultural professional group informatization construction of curriculum system development and the actual needs of the local economy and society closely, promote personnel training mode, the overall reform of the curriculum system, teaching content, teaching management, teaching methods and means.

In higher vocational professional group "modern agricultural research Internet plus" curriculum reform, carries on the discussion will focus on the curriculum system, teaching mode, teaching management and teaching effect. Agricultural vocational colleges are in an upward stage of development. Their teaching activities need certain theoretical and practical guidance. At the same time, they can also provide policy for education authorities to formulate policies and strengthen guidance for agricultural vocational colleges.

In higher vocational professional group "modern agricultural research Internet plus" curriculum reform is to cultivate high-quality skilled talents to meet the needs of the needs of the construction of new socialist countryside.

\section{Conclusions}

The construction of new socialist countryside agriculture needs a large number of high-quality skilled talents, the agricultural vocational colleges professional group curriculum system of modern agriculture informatization construction as the main content, to provide protection for agricultural cultivation of high-quality talents, contribute to the Agricultural Higher Vocational Colleges to cultivate high-quality skilled talents to agricultural and rural economic and social development.

\section{Acknowledgements}

This work was sponsored by Qing Lan Project, supported by the research subject of higher education reform in Jiangsu (No. 2017JSJG348), the education "13th Five-Year" Planning issues of Jiangsu province (No. B-b/2016/03/41), the modern educational technology research project of Jiangsu province (No. 2017-R-58821), and depth integration training platform of production and education of Jiangsu Province on 2016 (The depth integration training platform of intelligent digital plant factory production of production and education). 


\section{References}

[1] Z.H. Zhou, P.Y. Zhang: TELTCOM WORLD, Vol. 41 (2015) No.6, p.255 (In Chinese).

[2] N. Liu: Wireless Internet Technology, Vol. 4 (2016) No.7, p.83 (In Chinese).

[3] Information on http://theory.people.com.cn/n1/2017/0314/c148980-29143926.html.

[4] B.P. Wang: Applied Mechanics and Materials, Vol. 513 (2014) No.7, p.2987.

[5] Information on http://lianghui.people.com.cn/2017/n1/2017/0305/c410899-29124148.html.

[6] Information on http://www.sohu.com/a/113758491_418419.

[7] H.O. Huang: Industrial \& Science Tribune, Vol. 16 (2017) No.4, p.195 (In Chinese).

[8] Y.J. Zhang: Journal of Jilin Province Economic Management Cadre College, Vol. 166 (2016) No.6, p.89 (In Chinese). 